\title{
Proteinemia as a Prognostic Factor in Colorectal Cancers beyond Surgery and Chemotherapy
}

\author{
Linah Waleed Khalid Al-Hishma10 \\ ${ }^{1}$ National Cancer Center, Baghdad Medical City, Ministry of \\ Health/Environment, Baghdad, Iraq \\ J Coloproctol 2021;41(3):249-256.
}

\begin{abstract}
Address for correspondence Linah Waleed Khalid Al-Hishma, B. Sc. Pharmacy, Department of Pharmacy, Baghdad Medical City, Baghdad 10001, Iraq (e-mail: joym7131@gmail.com).
\end{abstract}

\begin{abstract}
Background Globally, 1,096,601, 704,376, and 48,541 new colon, rectum, and anus cancer cases were recorded in 2018, respectively. Besides, 551,269, 310,394 and 19,129 cases of colon, rectum, and anus cancer deaths occurred in the same year. As a result, these cancers ranked in the third level of cancer incidence, and in the second level of cancer mortality. As it is known, all cancer patients are subjected to cancerinduced and therapy-induced nutritional deficiencies (mainly of proteins and calories). The present study aimed to assess proteins level in colorectal cancer (CRC) patients who underwent surgery and chemotherapy.

Methods A combined retrospective and prospective study was performed. The present study enrolled 100 CRC patients with their data on surgical procedures and chemotherapy management. Assessments of the studied samples were conducted as a baseline before receiving chemotherapy and preoperatively as $\mathbf{P 0}$, while the period after that was termed as $\mathbf{P 1}$. The serum samples were collected to measure protein concentration. Total Protein Kit, Micro was used.

Results The mean age of the patients was $50.7 \pm 12.88$ years old. Only $8 \%$ had a positive CRC family history. Rectosigmoid cancer represented the most frequent site, figured in $41 \%$ of the cases, followed by rectum cancer. Multiple sites of CRC metastasis were recorded in $15 \%$ of the patients. All patients received chemoradiation. Folinic acid (leucovorin), 5-FU, and oxaliplatin (FOLFOX) was the most used regimen, administered in $40 \%$ of the patients. Oxaliplatin and capecitabine (also called Xeloda) (XELOX) were administered in $14 \%$ of the patients. Folinic acid (leucovorin), 5-FU, oxaliplatin, and irinotecan (FOLFOXIRI) were administered in $16 \%$ of the patients. Single-agent

Keywords

- colon cancer

- rectal cancer

- anal cancer

- chemoradiation

- proteinemia oxaliplatin or carboplatin were administered in $6 \%$ of the patients, each. 5 -FU plus leucovorin was administered to $12 \%$ of the patients. Three patients received irinotecan, and oxaliplatin (IROX). One patient received folinic acid (leucovorin), 5-FU and irinotecan (FOLFIRI). Also, Gemzar was administered to two patients only. A total of $80 \%$ of the patients underwent several surgical procedures. Anterior perineal resection (APR) and total mesorectal excision (TME) were the most common two surgeries,
\end{abstract}

received

January 9, 2021

accepted after revision

March 22, 2021

published online

July 19, 2021
DOI https://doi.org/

10.1055/s-0041-1730368.

ISSN 2237-9363. (c) 2021. Sociedade Brasileira de Coloproctologia. All rights reserved.

This is an open access article published by Thieme under the terms of the Creative Commons Attribution-NonDerivative-NonCommercial-License, permitting copying and reproduction so long as the original work is given appropriate credit. Contents may not be used for commercial purposes, or adapted, remixed, transformed or built upon. (https://creativecommons.org/ licenses/by-nc-nd/4.0/)

Thieme Revinter Publicações Ltda., Rua do Matoso 170, Rio de Janeiro, RJ, CEP 20270-135, Brazil 
performed in 20 and in $30 \%$ of the patients, respectively. In P0 status, $44 \%$ of the patients suffered from low protein levels, and $13 \%$ of the patients were within the normal level. These findings were statistically different $(p=0.03)$. After CRC management (i.e., P1 status), $70 \%$ of the patients had protein deficiency. These results have strong significant differences $(p=0.000)$. The mean of protein concentration declined gradually after management, from $8.82 \pm 0.9 \mu \mathrm{g} / \mathrm{L}$ to $6.21 \pm 0.78 \mu \mathrm{g} / \mathrm{L}$, with a strong association between a reduction in proteins levels towards deficiency and surgical procedures and chemotherapy protocols $(p=0.000)$.

Conclusion The incidence of CRC is increasing annually, and the chance of being diagnosed with this type of cancer has risen in recent years. In the present study, the male to female ratio was $1: 1.5$, and the $5^{\text {th }}$ decade of life was the most common age for the diagnosis of CRC. A negative family history and bowel inflammatory diseases (IBD) history did not exclude people from exposure to the incidence of CRC. Colorectal cancer with localized and moderately differentiated adenocarcinoma were the most common types in the present work. Tumor distance from the anal verge seems to be very important and plays a significant role in the choosing of surgical intervention types and chemoradiation protocols. Colorectal cancer acts as a complex condition and, in addition to its management, nutritional state influences it in different mechanisms. Most patients suffered from hypoproteinemia after surgery and chemoradiation. As a result, alteration in the treatment outcomes, delaying in wound healing, and an increase in postoperative complications may occur.

\section{Introduction}

Globally, 1,096,601, 704,376 and 48,541 new colon, rectum, and anus cancer cases were recorded in 2018 , respectively. ${ }^{1}$ Besides, 551,269, 310,394 and 19,129 cases of colon, rectum, and anus cancer deaths occurred in the same year. ${ }^{1-4}$ As a result, these cancers ranked in the third level of cancer incidence, and in the second level of cancer mortality. ${ }^{1}$ The incidence rates are higher, which is about 3 -fold in developed countries in comparison with developing countries. ${ }^{1}$

In 2018, Bray et al. ${ }^{1}$ mentioned in a Global Observatory Cancer (GLOBOCAN) reports that European countries have the highest colon cancer incidence rates, besides Australia, Northern America, and Eastern Asia. Although they reported similar incidence rates of rectal cancers, ${ }^{1}$ whereas colorectal cancer (CRC) incidence rates are low in Africa and Southern Asia. ${ }^{1}$ In Iraq, the Iraqi Cancer Registry (ICR) recorded 1,086 cases of CRC in 2011, and this number raised to 1,454 patients in $2015 .^{5,6} \mathrm{In}$ 2020, Siegel et al. ${ }^{7}$ reported $\sim 147,950$ individuals newly diagnosed with CRC in the USA and 53,200 deaths.

Those cancers are considered as a marker of socioeconomic development of countries, ${ }^{1}$ and planning the assessment of the clinical alterations that occur in these diseases is necessary for choosing the adequate proteins intervention with the best impact on nutritional status, body composition, treatment efficacy and, ultimately, to reduce complications and improve survival and quality of life. ${ }^{8}$ The increment in the incidence rates of CRC may be altered by dietary patterns, obesity, and lifestyle factors. ${ }^{1,8}$
In addition, when assessing CRC risk factors, World Cancer Research Fund/American Institute for Cancer Research (WCRF/AICR) recorded data with convincing evidence that red meat, alcoholic drinks, and body fatness raises risk, whereas physical activities are protective. ${ }^{1,9}$

As it is known, all cancer patients are subject to cancerinduced and therapy-induced nutritional deficiencies (mainly protein and caloric). ${ }^{8,10,11}$ These conditions are not solved by the consumption of high-protein nutrients, and the pathophysiology behind that is induced by metabolic alterations caused by the presence of CRC. ${ }^{11}$ The primary potentially curative therapy for CRC is surgery, in addition to chemotherapy and radiotherapy in neoadjuvant and adjuvant forms. ${ }^{2-4,11,12}$

The present study tries to assess protein concentration as a nutrient and prognostic factor in CRC patients who underwent surgery and chemotherapy.

\section{Methods}

\section{Study Setting and Design}

The present study was a combined retrospective and prospective study performed at the National Cancer Center during the period from January 2019 to May 2019. The present study enrolled 100 CRC patients with their data on surgical procedures and chemotherapy management. Assessments of the studied samples were be conducted as a baseline before receiving chemotherapy and preoperatively as $\mathbf{P 0}$, while the period afterwards was termed as $\mathbf{P 1}$. 


\section{Inclusion Criteria}

1. All CRC patients.

2. All patients aged $\geq 18$ years old.

\section{Exclusion Criteria}

1. Patients in the postoperative state and/or in the second cycle of chemotherapy.

2. Unstable patients.

\section{Data Collection}

Data collected included gender, age, family history, smoking, alcoholism, comorbidity, bowel inflammatory diseases (BID), tumor site, histopathology, stage, grade, tumor distance from the anal verge, metastasis, surgery type, chemoradiotherapy (CRT).

\section{Sample Collection}

The serum samples were left to clot for $\sim 2$ hours, then were centrifuged for 20 minutes at $1000 \times \mathrm{g}$. Then, the supernatant was collected, ${ }^{13}$ using the Total Protein Kit, Micro; 2020, Sigma-Aldrich Co. LLC.; St. Louis; USA (Catalog no. TP0100). ${ }^{13}$

\section{Principle}

The process was a sandwich enzyme-linked immunosorbent assay (ELISA) technology, ${ }^{13}$ and the biotin conjugated antiTotal HSP-90 antibody was used as detection antibody. ${ }^{13}$

\section{Preparation}

We diluted $30 \mathrm{~mL}$ of concentrated wash buffer into $750 \mathrm{~mL}$ of wash buffer with distal water (DW). The $100 \mathrm{ng} / \mathrm{ml}$ of standard solution (SS) was prepared by adding $1 \mathrm{ml}$ of sample/standard dilution buffer into one standard tube and mixing. An aliquot of $0.3 \mathrm{ml}$ of the sample/standard dilution buffer was deposited into each tube. Then, $0.3 \mathrm{ml}$ of the $100 \mathrm{ng} / \mathrm{ml} \mathrm{SS}$ was added of into the first tube and mixed. ${ }^{13}$

\section{Procedure}

Starting by aliquot $0.1 \mathrm{ml}$ of $100 \mathrm{ng} / \mathrm{ml}, 50 \mathrm{ng} / \mathrm{ml}, 25 \mathrm{ng} / \mathrm{ml}$, $12.5 \mathrm{ng} / \mathrm{ml}, 6.25 \mathrm{ng} / \mathrm{ml}, 3.125 \mathrm{ng} / \mathrm{ml}, 1.563 \mathrm{ng} / \mathrm{ml}$, standard solutions into the standard wells. Then, $0.1 \mathrm{ml}$ of sample/standard dilution buffer was added into the control well. Then, $0.1 \mathrm{ml}$ of diluted sample was added into test wells. Then, the plate was sealed with a cover and was incubated at $37^{\circ} \mathrm{C}$ for 90 minutes. Afterwards, the content was discarded and the plate was clapped on absorbent filter papers. Then, $0.1 \mathrm{ml}$ of Biotin-detection antibody was added into the standard, the test sample, and the zero wells. Then, the plate was sealed and incubated at $37^{\circ} \mathrm{C}$ for 60 minutes. Then, the plate was washed 3 times with Wash Buffer (Sigma-Aldrich Co. LLC.; St. Louis; USA). Then, $0.1 \mathrm{ml}$ of Strept Avidin-Biotin Complex (SABC) working solution was added into each well, the plate was covered, and the working solution was incubated at $37^{\circ} \mathrm{C}$ for 30 minutes, then it was washed 5 times with Wash Buffer. Afterwards, $90 \mu$ of TMB substrate was added into each well, the plate was covered, and the substrate was incubated at $37^{\circ} \mathrm{C}$ in the dark for between 15 and 30 minutes. Finally, $50 \mu \mathrm{l}$ of stop solution was added into each well and mixed. ${ }^{13}$

\section{Statistical Analysis}

Patient data were entered and analyzed using the IBM SPSS Statistics for Windows, Version 25 (IBM Corp., Armonk, NY, USA). Descriptive statistics were presented as mean, standard deviation (SD), frequencies, and proportions. Statistical tests were applied according to the type of variables; a Paired $t$-test for grouped samples was used to compare the means of a continuous variable. The Pearson correlation (2-sided) test was used to compared grouped samples. A level of significance of $p$ $\leq 0.05$ was considered a significant difference or correlation.

\section{Results}

The present study was composed of $40 \%$ male and $60 \%$ female subjects, with a mean of age of $50.7 \pm 12.88$ years old.

Most of the patients with CRC were between 51 and 60 years old, corresponding to $26 \%$ of the sample. Only $8 \%$ of the patients had a positive family history of CRC. Smoking patients corresponded to $60 \%$ of the sample, and the nonsmokers to $40 \%$. A total of $29 \%$ of the patients were alcoholics. A total of 49 out of 100 patients were obese. Body surface area (BSA) was above the normal index in $49 \%$ of the sample. Comorbidities were present in $38 \%$ of the sample. A total of $10 \%$ of the patients had IBD, while $90 \%$ did not present IBD. A total of $72 \%$ of CRC patients lived in the capital Baghdad. A total of $45 \%$ of females were housewives. A total of $25 \%$ of the patients did not work. (-Table $\mathbf{1}$ ).

Rectosigmoid cancer represented the most frequent site, corresponding to $41 \%$ of the cases, followed by rectum cancer. Adenocarcinoma was the most common histopathology, diagnosed in $66 \%$ of the patients. The tumors were localized in $46 \%$ of the cases, whereas spreading was found in $34 \%$ of the patients. Moderate differentiation was observed in $60 \%$ of the patients, while poorly-patterned tumors were present in $15 \%$ of the patients. A total of 15 (15\%) tumors were located at a distance $<5 \mathrm{~cm}$ from the anal verge, while those located at a distance between 5 and $10 \mathrm{~cm}$ corresponded to 40 (40\%) of the cases. Tumors at a distant location from the anal verge corresponded to $45 \%$. Multiple sites of CRC metastasis were recorded in $15 \%$ of the cases. Hepatic lesions were seen in 6 patients. Pulmonary metastases were found in two patients. Lytic bony lesions were present in $5 \%$ of the patients. Recurrence was present in $6 \%$ of the cases, while $66 \%$ of the patients did not have metastasis. (- Table $\mathbf{1}$ ).

All patients received chemoradiation. Folinic acid (leucovorin), 5-FU, and oxaliplatin (FOLFOX) were administered in $40 \%$ of the patients, and was the most used regimen. Oxaliplatin and capecitabine (also called Xeloda) (XELOX) were administered to $14 \%$ of the patients. Folinic acid (leucovorin), 5-FU, oxaliplatin, and irinotecan (FOLFOXIRI) were administered in $16 \%$ of the patients. Single-agent oxaliplatin or carboplatin were administered to $6 \%$ of the patients, each. 5-FU plus leucovorin were administered to $12 \%$ of the patients. Three patients received irinotecan, and oxaliplatin (IROX). One patient received folinic acid (leucovorin), 5-FU, and irinotecan (FOLFIRI). In addition, Gemzar was administered to only two patients ( - Table $\mathbf{1}$ ). 
Table 1 Patients, colorectal cancer, and management baseline characteristics $(n=100)$

\begin{tabular}{|c|c|c|}
\hline \multicolumn{2}{|l|}{ Variables } & \multirow{2}{*}{$\frac{n(\%)}{40(40)}$} \\
\hline Gender & Male & \\
\hline & Female & $60(60)$ \\
\hline \multirow{6}{*}{$\begin{array}{l}\text { Age (years old) } \\
50.7 \pm 12.88\end{array}$} & $20-30$ & $4(4)$ \\
\hline & $31-40$ & $10(10)$ \\
\hline & $41-50$ & $16(16)$ \\
\hline & $51-60$ & $26(26)$ \\
\hline & $61-70$ & $24(24)$ \\
\hline & $>70$ & $20(20)$ \\
\hline \multirow[t]{2}{*}{ Family history } & Positive & $8(8)$ \\
\hline & Negative & $92(92)$ \\
\hline \multirow[t]{2}{*}{ Smoking } & Smoker & $60(60)$ \\
\hline & Nonsmoker & $40(40)$ \\
\hline \multirow[t]{2}{*}{ Alcoholism } & Yes & $29(29)$ \\
\hline & No & $71(71)$ \\
\hline \multirow{3}{*}{$\begin{array}{l}\text { BSA }\left(\mathrm{m}^{2}\right) \\
1.7 \pm 0.39\end{array}$} & $<1.7$ & $31(31)$ \\
\hline & 1.7 & $20 \quad 20)$ \\
\hline & $>1.7$ & 49 (49) \\
\hline \multirow[t]{2}{*}{ Comorbidity } & Present & $38(38)$ \\
\hline & Absent & $62(62)$ \\
\hline \multirow[t]{2}{*}{ IBD } & Present & $10(10)$ \\
\hline & Absent & $90(90)$ \\
\hline \multirow[t]{9}{*}{ Address } & Babil & $4(4)$ \\
\hline & Baghdad & $72(72)$ \\
\hline & Basra & $1(1)$ \\
\hline & Diyala & $6(6)$ \\
\hline & Misan & $1(1)$ \\
\hline & Musol & $2(2)$ \\
\hline & Ramadi & $4(4)$ \\
\hline & Tikreit & $5(5)$ \\
\hline & Wasit & $5(5)$ \\
\hline \multirow[t]{4}{*}{ Occupation } & Government employed & $24(24)$ \\
\hline & Nonemployed & $25(25)$ \\
\hline & Housewife & $45(45)$ \\
\hline & Student & $6(6)$ \\
\hline \multirow{7}{*}{$\begin{array}{l}\text { Colorectal } \\
\text { cancer sites }\end{array}$} & Rectum & $25(25)$ \\
\hline & Anorectal & $8(8)$ \\
\hline & Rectosigmoid & $41(41)$ \\
\hline & Cecum & $3(3)$ \\
\hline & Right colon & $10(10)$ \\
\hline & Transverse & $5(5)$ \\
\hline & Left colon & $8(8)$ \\
\hline \multirow[t]{2}{*}{ Histopathology } & Adenocarcinoma & $66(66)$ \\
\hline & Mucinous & $12(12)$ \\
\hline
\end{tabular}

Table 1 (Continued)

\begin{tabular}{|c|c|c|}
\hline \multicolumn{2}{|l|}{ Variables } & \multirow{2}{*}{$\frac{n(\%)}{4(4)}$} \\
\hline & Signet-ring cell & \\
\hline & Undifferentiated & $10(10)$ \\
\hline & Adenosquamous & $4(4)$ \\
\hline & Squamous & $4(4)$ \\
\hline \multirow[t]{3}{*}{ Stages } & Localized & $46(46)$ \\
\hline & Regional & $20(20)$ \\
\hline & Distant metastasis & $34(34)$ \\
\hline \multirow[t]{3}{*}{ Grades } & Well differentiated & $25(25)$ \\
\hline & Moderately differentiated & $60(60)$ \\
\hline & Poorly differentiated & $15(15)$ \\
\hline \multirow{3}{*}{$\begin{array}{l}\text { Distance from } \\
\text { the anal verge }\end{array}$} & $<5 \mathrm{~cm}$ & $15(15)$ \\
\hline & $5-10 \mathrm{~cm}$ & $40(40)$ \\
\hline & $>10 \mathrm{~cm}$ & $45(45)$ \\
\hline \multirow{6}{*}{$\begin{array}{l}\text { Metastatic } \\
\text { patterns }\end{array}$} & Liver & $6(6)$ \\
\hline & Lung & $2(2)$ \\
\hline & Local recurrence & $6(6)$ \\
\hline & Bone & $5(5)$ \\
\hline & Multiple metastases & $15(15)$ \\
\hline & No metastases & $66(66)$ \\
\hline \multirow[t]{2}{*}{ Chemotherapy } & Received & $100(100)$ \\
\hline & No & 0 \\
\hline \multirow{9}{*}{$\begin{array}{l}\text { Chemotherapy } \\
\text { protocols }\end{array}$} & 5-FU plus leucovorin & $12(12)$ \\
\hline & FOLFOX & $40(40)$ \\
\hline & XELOX & $14(14)$ \\
\hline & FOLFIRI & $1(1)$ \\
\hline & Oxaliplatin & $6(6)$ \\
\hline & IROX & $3(3)$ \\
\hline & FOLFOXIRI & $16(16)$ \\
\hline & Carboplatin & $6(6)$ \\
\hline & Gemzar & $2(2)$ \\
\hline \multirow[t]{2}{*}{ Radiotherapy } & Received & $100(100)$ \\
\hline & No & 0 \\
\hline \multirow[t]{7}{*}{ Surgery } & APR & $20(20)$ \\
\hline & LAR + loop ileostomy & $5(5)$ \\
\hline & LAR without ileostomy & $8(8)$ \\
\hline & TME & $30(30)$ \\
\hline & Local excision & $7(7)$ \\
\hline & Laparotomy & $10(10)$ \\
\hline & No surgery & $20(20)$ \\
\hline
\end{tabular}

Abbreviations: FOLFIRI; folinic acid (leucovorin), 5-FU, oxaliplatin, and irinotecan; FOLFOX, folinic acid (leucovorin), 5-FU, and oxaliplatin; FOLFOXIRI, folinic acid (leucovorin), 5-FU, oxaliplatin, and irinotecan; IROX, irinotecan and oxaliplatin; XELOX, oxaliplatin and capecitabine (also called Xeloda). 
Table 2 Protein concentration before and after $(n=100)$

\begin{tabular}{|c|c|c|c|c|c|}
\hline \multirow[t]{2}{*}{ Protein } & $\mathrm{PO}$ & P1 & \multirow[t]{2}{*}{ Paired $t$-test } & \multirow[t]{2}{*}{$95 \% \mathrm{Cl}$} & \multirow[t]{2}{*}{ p-value } \\
\hline & \multicolumn{2}{|l|}{$n(\%)$} & & & \\
\hline Hypoproteinemia (< $67 \mathrm{~g} / \mathrm{L}$ ) & $44(44)$ & $70(70)$ & \multirow[t]{5}{*}{5.281} & \multirow[t]{5}{*}{$38.285-84.374$} & \multirow[t]{5}{*}{0.000} \\
\hline Normal (67-86 gl/L) & $13(13)$ & $20(20)$ & & & \\
\hline Hyperproteinemia (>86 g/L) & $43(43)$ & $10(10)$ & & & \\
\hline Mean \pm SD & $8.82 \pm 0.9$ & $6.21 \pm 0.78$ & & & \\
\hline p-value (one-sample test) & 0.03 & 0.000 & & & \\
\hline
\end{tabular}

Abbreviations: $\mathrm{Cl}$, confidence interval; SD, standard deviation.

A total of $80 \%$ of the patients underwent several surgical procedures. APR and TME were the most common surgeries, performed in 20 and $30 \%$ of the patients, respectively. Local excision was performed in $7 \%$ of the patients. A total of $10 \%$ of the patients underwent laparotomy. Loop ileostomy was performed in $5 \%$ of the patients, whereas it was not done in $8 \%$ ( - Table 1 ).

In the P0 status, $44 \%$ of the patients suffered from low protein levels, $13 \%$ of the patients were within the normal level, and $43 \%$ of the patients had hypoproteinemia. These findings were statistically different $(p=0.03)$.

After CRC management (i.e., P1 status), $70 \%$ of the patients had protein deficiency. Normal protein levels were observed in $20 \%$ of the patients, while $10 \%$ of the patients still had a high concentration of proteins. These results have strong significant differences $(p=0.000)$ ( - Table 2).

The mean protein concentration declined gradually after management, from $8.82 \pm 0.9 \mu \mathrm{g} / \mathrm{L}$ to $6.21 \pm 0.78 \mu \mathrm{g} / \mathrm{L}$, with a strong association between a reduction in proteins level towards deficiency and surgical procedures and chemotherapy protocols $(p=0.000)$ ( - Table $\mathbf{2}$ ) (-Fig. $\mathbf{1}$ ).

\section{Discussion}

Several studies conducted in Iraq postulated different findings for CRC. Some of the studies agree with most of the results of the present study, such as those by Radhi et al., in Al-Diwaniyah, ${ }^{14}$ Alsafi et al., in Karbala, ${ }^{15}$ Alshewered et al., in Baghdad, ${ }^{2}$ Alrubaia et al., in Baghdad, ${ }^{3}$ while others were not in line with the present study, such as those by Alhilfi et al., in Misan, ${ }^{4}$ and by Khalil et al., in Duhok. ${ }^{16}$

In Iraq, the incidence of CRC is increasing annually, and the chance of being diagnosed has risen in recent years, which may be attributed to increased awareness of symptoms like bleeding per rectum (BPR) and constipation, and to the early detection of small lesions secondary to the more widespread use of colonoscopy, and fine-needle aspiration of any suspicious lesion in treatment centers.

In the present study, the male to female ratio was $1: 1.5$, and the $5^{\text {th }}$ decade of life was the common age for the diagnosis of CRC. Other researchers said that age is an essential factor for the occurrence and management of CRC, ${ }^{12,17}$ and reports registered in the ICR for a period of 10 years and in the National Cancer Hospitals for 3 years

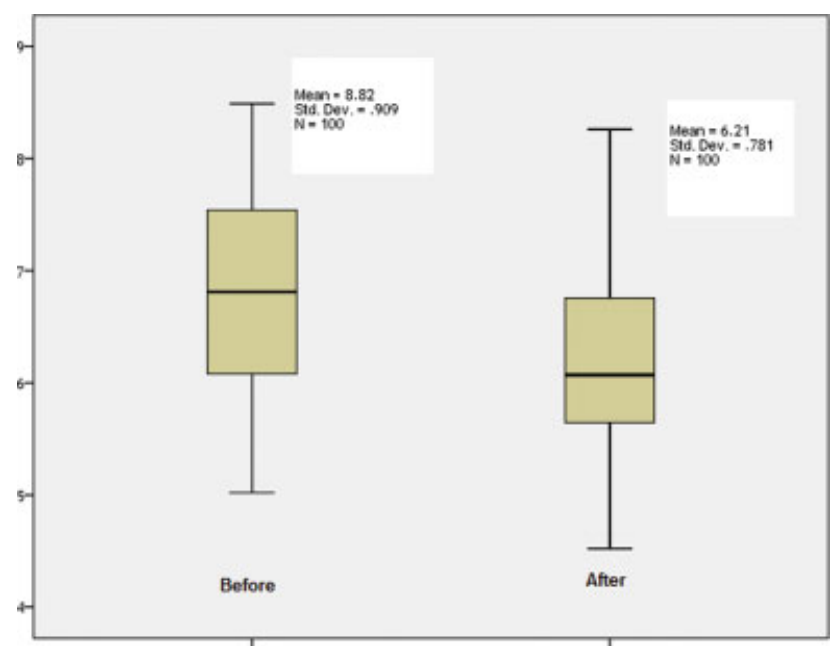

Fig. 1 Box plot of protein concentrations before and after surgery and chemotherapy of colorectal cancer (CRC).

found that the male to female ratio varied from 1.17:1 to $1.28: 1 .^{18}$

A negative family history and IBD history does not exclude people from exposure to CRC incidence. Tobacco smoking and alcohol consumption may be a risk, but the findings of the present study did not support that.

Different factors were shown to raise the risk of incidence of colon cancer, including older age, male gender, positive family history, IBD, being taller or obese, eating processed meat, refined grains, starches, and sugars, alcoholism and

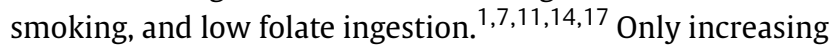
age, female gender, and excessive alcohol consumption have been associated with rectal cancer. ${ }^{7,12,14,17}$

With a low socioeconomic status, insufficient screening methods, doubtful early detection, low educational level, mistakes in diagnosis, and unavailability of diagnostic tools, the mean age of CRC diagnosis was $>50$ years old. In Western countries, $8 \%$ of CRC cases were recorded at ages $<40$ years old, whereas Egypt, Saudi Arabia, the Philippines, and Iran recorded rates of $38,21,17$, and between 15 and $35 \%$ for the same age group, respectively. ${ }^{6,19-21}$

There was no correlation between nutritional status and income, education, and type of IBD, and no correlation was 
observed between the most consumed anti-inflammatory and inflammatory foods and BMI. ${ }^{22}$

Most of the patients were addressed in Baghdad, which is the capital of Iraq. However, we received many colonoscopy reports from other sites.

Those may be reflected in the non-real figures due to several patients like to do a colonoscopy in different places and even outside Iraq, besides that many cases of CRC diagnosed by imaging studies and undergo surgery without doing colonoscopy or sigmoidoscopy, resulted in many missing cases.

Most of the studied patients had a rectosigmoid tumor, which is similar to that reported by Giovannucci et al., who reported that the most common site is the sigmoid, followed by the rectum, the cecum, the rectosigmoid junction, the transverse colon, and the ascending colon. ${ }^{23}$ However, these findings differ from those of other studies. $^{4,14-16}$

Localized and moderately differentiated CRC adenocarcinoma were the most common subtypes observed in the present study, which supports that CRC tumors originate in the mucosal layer and that all of them are adenocarcinomas. ${ }^{17}$ All researchers in Iraq support these findings. ${ }^{2-4,14-16,18,24}$

However, these findings are different from the Surveillance, Epidemiology, and End Results Program (SEER) data that reported the localized site of CRC was (47\%), regional (36.5\%), metastatic (16.5\%) of CRC cases. This can be due to different sample sizes, early diagnosis and treatment provided by screening programs, good health education, and awareness in the US and other developed countries. ${ }^{25,26}$

The distance of the tumors from the anal verge seems to be very important and plays a significant role in the decisionmaking regarding surgical intervention types and chemoradiation protocols. Here, most cases had tumors that were distant from the and verge (i.e., $>5 \mathrm{~cm}$ ). A study by Khan et al. reported that the distance of CRC from the anal verge influenced the use of neoadjuvant treatment and, ultimately, the $\mathrm{R} 0$ resection rate. The tumor location and the distal tumor margin are essential factors upon which the surgical plan for patients with CRC is based. Accurate measurement is necessary for planning the surgical procedure, even sphincter-saving resection. ${ }^{27}$

All patients received chemotherapy of different regimens, whether they were in early or advanced stages of CRC. Also, all patients were treated by radiotherapy (RT). Besides, $80 \%$ of the patients underwent surgery. All these management combinations followed international guidelines of several trials worldwide, such as the National Cancer Institute (NCI) and Mayo/NCCTG 79-47-51 trials; NSABP R-01, R-02 trials; EORTC trial 22921; NSABP R0-354 and the German CAO/ ARO/AIO 94 trials; STAR-01, ACCORD, and NSABP R-04 trials; UK MRC CR07 trial; Dutch Colorectal Cancer Group CKVO and Swedish Rectal Cancer trials; German Rectal Cancer Trial CAO/ARO/ AIO-94; and the Polish Colorectal Study Group trial. $^{11,28-34}$

As it is known CRC is a complex cancer and it influences the nutritional state in different manners. ${ }^{35}$ It is reported that between 15 and $40 \%$ of the patients have weight loss and that between 40 and $80 \%$ of the patients suffer from malnourishment during management. ${ }^{36}$

Regarding the results of proteinemia, most of the patients (70\%) suffered from hypoproteinemia after surgery and chemoradiation. In this state, malnutrition may develop and cause alterations in the treatment outcomes, delaying wound healing and increasing postoperative complications. Besides, malnutrition can cause impairment tolerance and response to chemotherapy. ${ }^{37}$ In addition to the disease, antineoplastic treatments and/or surgery have a significant impact on the nutritional status of the patients. ${ }^{14,34,38}$

During chemotherapy and radiotherapy, nausea and vomiting are very common and lead to poor nutritional status, which further increases surgical morbidity and postoperative complications. ${ }^{38-41}$

The nutritional supplement not presented for all cancerous patients, and this postulated a guide to the multidisciplinary team in the management of CRC for including nutritional intervention for those patients.

Cancer patients do not meet the recommended intake $(1.2-1.5 \mathrm{~g} / \mathrm{kg} /$ day $)$ of proteins, not even that recommended for healthy individuals $(0.8 \mathrm{~g} / \mathrm{kg} /$ day $) .{ }^{42}$ Limited protein intake documented mainly from nutrition impact symptoms that affect dietary intake. ${ }^{43}$ Recent guidelines suggest a higher range of protein intake $(1.2-1.5 \mathrm{~g} / \mathrm{kg} /$ day $)$ due to the positive results of higher protein intake in protein balancing and in maintaining muscle mass. Of additional interest is a recent study showing an inverse association between red meat consumption and 7-year mortality among 992 individuals with stage III colon cancer, ${ }^{44}$ suggesting that higher protein intake may be beneficial in cancer. In a review by Gangadharan et al., the authors explained in detail the effect of surgery, chemotherapy, and radiotherapy on protein concentrations in $\mathrm{CRC}^{10}$

\section{Conclusions}

The incidence of CRC is increasing annually, and the chance of being diagnosed has risen in recent years. In the present study, the male to female ratio was $1: 1.5$, and the $5^{\text {th }}$ decade of life was the most common age for the diagnosis of CRC. A negative family history and IBD history did not exclude individuals from exposure to CRC incidence. Localized and moderately differentiated CRC adenocarcinoma was the most common subtype in the present study. The distance of the tumors from the anal verge seems to be very important and plays a significant role in the decision-making regarding surgical intervention types and chemoradiation protocols. Colorectal cancer act as a complex condition, in addition to their management, are influences the nutritional state in different mechanisms. Most patients suffered from hypoproteinemia after surgery and chemoradiation. As a result, alteration in the treatment outcomes, delays in wound healing, and increase in postoperative complications may develop.

\section{Ethical Approval}

The present study followed the Declaration of Helsinki and was approved by the local ethics committee of the 
center. Informed written consent was obtained from all patients.

\section{Conflict of Interests}

The authors have no conflict of interests to declare.

\section{Acknowledgment}

All authors thank Dr. Mohammad F Al-Dahan from Creffiel medical Centre (London, UK), and Dr. Ahmed Alshewered from Misan Radiation Oncology Center (Misan, Iraq) for their help.

\section{References}

1 Bray F, Ferlay J, Soerjomataram I, Siegel RL, Torre LA, Jemal A. Global cancer statistics 2018: GLOBOCAN estimates of incidence and mortality worldwide for 36 cancers in 185 countries. CA Cancer J Clin 112018;68(06):394-424. Doi: 10.3322/caac.21492. Epub 2018 Sep 12. Erratum in: CA Cancer J Clin. 2020 Jul;70 (4):313. PMID: 30207593

2 Alrubai, Alaa Mobder Mohammed, Al-Naqqash, Manwar Abdulelah, \& Alshewered, Ahmed Salih. 2020Epidemiological and prognostic single center study of anal carcinoma. Journal of Coloproctology (Rio de Janeiro)40(03):202-208. Epub August 14, 2020. https://doi.org/10.1016/j.jcol.2020.01.003

3 Alrubai, Alaa Mobder Mohammed, Al-Naqqash, Manwar Abdulelah, \& Alshewered, Ahmed Salih. 2020Epidemiological and prognostic single center study of anal carcinoma. Journal of Coloproctology (Rio de Janeiro)40(03):202-208. Epub August 14, 2020. https://doi.org/10.1016/j.jcol.2020.01.003

4 Alhilfi, Haider Saadoon Qasim, Almohammadawi, Khalid Obiad Mohsin, Alsaad, Rasha Khalil Abduljalil, Ameen, Nyaz Ahmed, Aliedani, Basima Kadhim Abbood, Aldubaisi, Husam Jihad Imran, \& Alshewered, Ahmed Salih Hussien. 2019Colorectal cancer epidemiology and clinical study in Misan. Journal of Coloproctology (Rio de Janeiro)39(02):159-162. Epub June 13, 2019. https:// doi.org/10.1016/j.jcol.2018.12.001

5 Iraqi Cancer Registry. Ministry Of Health, Iraqi Cancer Board, Baghdad, Iraq. 2011https://moh.gov.iq/upload/upfile/ar/273.pdf

6 Iraqi Cancer Registry Annual Report. Iraqi Cancer Registry Board, Ministry Of Health and Environment. Baghdad, Iraq2015

7 Siegel RL, Miller KD, Goding Sauer A, Fedewa SA, Butterly LF, Anderson JC, Cercek A, Smith RA, Jemal A. Colorectal cancer statistics, 2020. CA Cancer J Clin 052020;70(03):145-164. Doi: 10.3322/caac.21601. Epub 2020 Mar 5. PMID: 32133645

8 Ravasco P. Nutrition in Cancer Patients. J Clin Med. 14082019;8 (08):1211. Doi: 10.3390/jcm8081211. PMID: 31416154; PMCID: PMC6723589

9 World Cancer Research Fund/American Institute for Cancer Research (WCRF/AICR) Continuous Update Project Report: Diet, Nutrition, Physical Activity and Colorectal Cancer 2016. Revised 2018 London: World Cancer Research Fund International; 2018aicr.org/continuous-update-project/reports/colorectal-cancer-2017-report.pdf

10 Gangadharan A, Choi SE, Hassan A, et al. Protein calorie malnutrition, nutritional intervention and personalized cancer care. Oncotarget 2017;8(14):24009-24030

11 NCCN. 2020Clinical Practice Guidelines in Oncology. Colon, Rectal, and Anal Cancers Version.2 www.ncen.org

12 Alberts SR, Grothy A. In: Casciato DA and Territo MC (editors). Manual of Clinical Oncology: Colorectal cancer 7th edt. Lippincott Williams \& Wilkinsa Wolters Kluwer business. USA2012:239-258

13 https://www.sigmaaldrich.com/content/dam/sigma-aldrich/docs/Sigma/Bulletin/tp0100bul.pdf

14 Radhi AA, Muslim OT, Abdlmaged MA. Epidemiological distribution of colorectal cancer in AL-Diwaniyah province, Iraq: an observational study. J Pharm Sci \& Res. 2018;10(07):1758-1760 available at https://www.jpsr.pharmainfo.in/Documents/Volumes/vol10Issue07/jpsr10071831.pdf

15 Alsafi RAR, Metib NJ, Hameedi AD, et al. The Clinical and Pathological Characteristics of Colorectal Cancer in Young Age Group in Karbala Province/Iraq. Karbala J Med. 2018;11(02):4025-4031. available at https://journals.uokerbala.edu.iq/index.php/kj/article/view/372

16 Khalil KH, Al-Hassawi BA, Abdo JM. Histopathological evaluation of colorectal carcinoma. Duhok Medical Journal 2018;12(02): 45-68. available at https://www.iasj.net/iasj/article/162945

17 Palta M, Willett CG, Czito BG. Principles and practice of radiation oncology: Cancer of the Colon and Rectum. In: Halperin EC, Perez CA, Brady LW, et al., (editors) 6th ed. Philadelphia: Lippincott Williams \& Wilkins; 2013:1215-1230

18 Al Dahhan SA, Al Lami FH. Epidemiology of Colorectal Cancer in Iraq, 2002-2014. Gulf J Oncolog 2018 Jan01(26):23-26. PMID: 29607818

19 https://www.nice.org.uk/The National Institute for Health and Care Excellence/guidance/cg131/ colorectal cancer diagnosis and management/. 2014

20 http://publications.iarc.fr/The International Agency for Research on Cancer/Non-Series-Publications/World cancer report/. 2014

21 http://www.who.int/cancer/colorectal/en/2014

22 Dilly RS, Barretta $\mathrm{C}$, Matos $\mathrm{CH}$, et al. Nutritional status and consumption of inflammatory and anti-inflammatory foods by patients with inflammatory bowel diseases. J Coloproctol (Rio J) 2020;40(02):99-104. Available at https://www.scielo.br/pdf/ jcol/v40n2/2237-9363-jcol-40-02-0099.pdf

23 Giovannucci E, Wu K. Cancer Epidemiology and Prevention: cancer of the colon and rectum. In: Schottenfeld D, Fraumeni JF. 3rd Edition Oxford University Press, Inc.USA2006:809-830

24 Khalid OMA, Haider SQA, Ahmed SHA. Epidemiological data of 1418 Cancer Cases of Inpatient in Al-Sadder Teaching Hospital, Misan Province from 2011-2018 (Surveillance Study). Med Sci 2018;22(93):455-461. Available at https://www.researchgate.net/publication/326775771_Epidemiological_data_of_1418_Cancer_ Cases_of_Inpatient_in_Al-Sadder_Teaching_Hospital_Misan_Province_from_2011-2018_Surveillance_Study

25 www.seer.cancer.gov/statfacts/html/anus.html

26 Franklin RA, Giri S, Valasareddy P, Lands LT, Martin MG. Comparative Survival of Patients With Anal Adenocarcinoma, Squamous Cell Carcinoma of the Anus, and Rectal Adenocarcinoma. Clin Colorectal Cancer 032016;15(01):47-53. Doi: 10.1016/j. clcc.2015.07.007. Epub 2015 Aug 1. PMID: 26362848.

27 Khan MAS, Ang CW, Hakeem AR, Scott N, Saunders RN, Botterill I. The Impact of Tumour Distance From the Anal Verge on Clinical Management and Outcomes in Patients Having a Curative Resection for Rectal Cancer. J Gastrointest Surg. 122017;21(12): 2056-2065. Doi: 10.1007/s11605-017-3581-0. Epub 2017 Sep 18. PMID: 28924962

28 Mohiuddin M, Willett CG. In: Halperin EC, Perez CA, Brady LW, et al., (editors) Principles and practice of radiation oncology: Colon and Rectum. 6th ed. Philadelphia: Lippincott Williams \& Wilkins; 2015:1366-1382

29 Bosset JF, Calais G, Mineur L, et al. Fluorouracil-based adjuvant chemotherapy after preoperative chemoradiotherapy in colorectal cancer: Long-term results of the EORTC 22921 randomised study. Lancet Oncol 2014;15:184-190

30 Sauer R, Liersch T, Merkel S, et al. Preoperative versus postoperative chemoradiotherapy for locally advanced colorectal cancer: Results of the German CAO/ARO/AIO-94 randomized phase III trial after a median follow-up of 11 years. J Clin Oncol 2012; 30:1926-1933

31 Quirke P, Steele R, Monson J, et al. Effect of the plane of surgery achieved on local recurrence in patients with operable colorectal cancer: A prospective study using data from the MRC CR07 and NCICCTG Co16 randomised clinical trial. Lancet 2009;373:821-828 
32 Bosset JF, Collette L, Bardet E, et al. Chemotherapy with preoperative radiotherapy in colorectal cancer. N Engl J Med 2006; 355:1114-1123

33 Smalley SR, Benedetti JK, Williamson SK, et al. Phase III trial of fluorouracil-based chemotherapy regimens plus radiotherapy in postoperative adjuvant colorectal cancer: GI INT 0144. J Clin Oncol 2006;24:3542-3547

34 Gunderson LL, Sargent D, Tepper JE, et al. Impact of T and N stage and treatment on survival and relapse in adjuvant colorectal cancer: A pooled analysis. J Clin Oncol 2004;22:1785-1796

35 Mattox TW. Cancer Cachexia: Cause, Diagnosis, and Treatment. Nutr Clin Pract 2017;32:599-606

36 Ravasco P, Grillo IM, Vidal P, et al. Nutritional Deterioration in Cancer: The Role of Disease and Diet. Clin Oncol 2003;15:443-450

37 Mantzorou M, Koutelidakis A, Theocharis S, et al. Clinical Value of Nutritional Status in Cancer: What is its Impact and how it A_ects Disease Progression and Prognosis? Nutr Cancer 2017;69:1-26

38 Weimann A, Braga M, Carli F, et al. ESPEN guideline: Clinical nutrition in surgery. Clin Nutr 2017;36:623-650

39 Blauwho-Buskermolen S, Versteeg KS, De Van Der Schueren MA, et al. Loss of Muscle Mass During Chemotherapy Is Predictive for
Poor Survival of Patients with Metastatic Colorectal Cancer. J Clin Oncol 2016;34:1339-1344

40 Ravasco P, Monteiro Grillo I, Marques Vidal P, et al. Dietary conseling improves patient outcomes: A prospective, randomized, controlled trial in colorectal cancer patients undergoing radiotherapy. J Clin Oncol 2005;23:1431-1438

41 Lieffers JR, Bathe OF, Fassbender K, et al. Sarcopenia is associated with postoperative infection and delayed recovery from colorectal cancer resection surgery. Br J Cancer 2012;107:931-936

42 Deutz NE, Safar A, Schutzler S, et al. Muscle protein synthesis in cancer patients can be stimulated with a specially formulated medical food. Clin Nutr 2011;30:759-768

43 Omlin A, Blum D, Wierecky J, et al. Nutrition impact symptoms in advanced cancer patients: Frequency and specific interventions, a case-control study. J Cachexia Sarcopenia Muscle 2013; 4:55-61

44 Van Blarigan EL, Fuchs CS, Niedzwiecki D, et al. Association of Survival with Adherence to the American Cancer Society Nutrition and Physical Activity Guidelines for Cancer Survivors After Colon Cancer Diagnosis: The CALGB 89803/Alliance Trial. JAMA Oncol 2018;4:783-790 